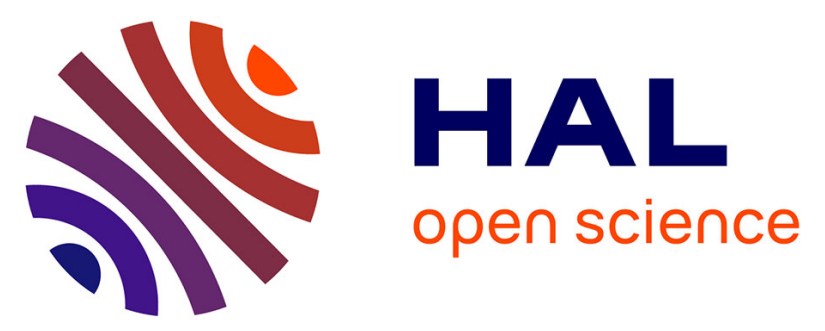

\title{
Ferroelectricity and high tunability in novel strontium and tantalum based layered perovskite materials
}

Florent Marlec, Claire Le Paven, François Cheviré, Laurent Le Gendre, Ratiba Benzerga, Benoit Guiffard, Thibault Dufay, Franck Tessier, Bachir Messaid, Ala Sharaiha

\section{To cite this version:}

Florent Marlec, Claire Le Paven, François Cheviré, Laurent Le Gendre, Ratiba Benzerga, et al.. Ferroelectricity and high tunability in novel strontium and tantalum based layered perovskite materials. Journal of the European Ceramic Society, 2018, 38 (6), pp.2526-2533. 10.1016/j.jeurceramsoc.2018.01.033 . hal-01740147

HAL Id: hal-01740147

https://hal-univ-rennes1.archives-ouvertes.fr/hal-01740147

Submitted on 4 Oct 2018

HAL is a multi-disciplinary open access archive for the deposit and dissemination of scientific research documents, whether they are published or not. The documents may come from teaching and research institutions in France or abroad, or from public or private research centers.
L'archive ouverte pluridisciplinaire HAL, est destinée au dépôt et à la diffusion de documents scientifiques de niveau recherche, publiés ou non, émanant des établissements d'enseignement et de recherche français ou étrangers, des laboratoires publics ou privés. 


\title{
Ferroelectricity and High Tunability in Novel Strontium and Tantalum Based Layered Perovskite Materials
}

\author{
Florent Marlec ${ }^{\S}$, Claire Le Paven ${ }^{\S}$, François Cheviré ${ }^{\ddagger}$, Laurent Le Gendre ${ }^{\S}$, Ratiba Benzerga ${ }^{\S}$, Benoît Guiffard ${ }^{\S}$, Thibaut \\ Dufay $^{\S}$, Franck Tessier ${ }^{\ddagger}$, Bachir Messaid ${ }^{\S}$, Ala Sharaiha ${ }^{\S}$ \\ ${ }^{\S}$ Equipe FunMAT, Institut d'Electronique et de Télécommunications de Rennes (IETR), Université de Rennes 1, IUT Saint- \\ Brieuc 22000 Saint Brieuc, France \\ ${ }^{¥}$ Equipe Verres et Céramiques, Institut des Sciences Chimiques de Rennes (ISCR), Université de Rennes 135042 Rennes \\ cedex, France.

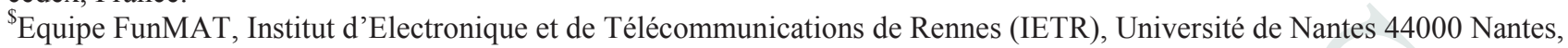 \\ France.
}

\begin{abstract}
The present study reveals the ferroelectric nature of the novel $\left(\mathrm{Sr}_{2} \mathrm{Ta}_{2} \mathrm{O}_{7}\right)_{100-\mathrm{x}}\left(\mathrm{La}_{2} \mathrm{Ti}_{2} \mathrm{O}_{7}\right)_{\mathrm{x}}$ layered perovskite materials and highlights a large variation of their permittivity under electric fields associated with very low dielectric loss in the radio-frequency range. More precisely, an ideal solid solution has been evidenced within the composition range $0 \leq \mathrm{x} \leq 5$ with lattice parameters and cell volume varying linearly with $\mathrm{x}$. The relative permittivity also depends on the composition and reaches a maximum value $(365 @ 10 \mathrm{kHz}, \mathrm{RT})$, associated with a high tunability $(17.6 \% 0.38 \mathrm{kV} / \mathrm{mm})$ with very low dielectric loss lower than $2.10^{-3}$. Variation of the relative permittivity as a function of the temperature is also demonstrated, with the existence of a temperature maximum, increasing with the composition. Polarization-electric field (P-E) measurements feature hysteresis loops for compositions $\mathrm{x} \geq 1.85$, in conjunction with current peaks in the I-E curves originating from ferroelectric domains switching.
\end{abstract}

Keywords : perovskite - ferroelectric - tunability $-\mathrm{Sr}_{2} \mathrm{Ta}_{2} \mathrm{O}_{7}-\mathrm{La}_{2} \mathrm{Ti}_{2} \mathrm{O}_{7}$

\section{Introduction}

Designing and/or combining new functions in nomad and communicating objects constitute a multi-disciplinary work and a source of major innovations. The present article deals with this theme through the research of new functional materials for the development of agile telecommunication devices, in particular antennas. In this case, frequency agility can be achieved by replacing the multiband frequency antennas in the communicating system by a single one which is reconfigurable in frequency. The material route consists in associating the radiating element with a tunable material, one of whose properties can be controlled by an external excitation (electric field, magnetic field, temperature, mechanical strain, etc). Ferroelectric materials are then attractive candidates as their permittivity is tunable under DC electric field E [1]. In the form of dense ceramics, requirements for their integration in reconfigurable devices involve a moderate relative permittivity value $(\kappa=50-500)$ in order to achieve devices with industrially compatible dimensions, very low dielectric losses $(\tan \delta<1 \%)$ in order to limit the insertion losses of the device and a tunability higher than $10 \%$ for a field of $2 \mathrm{kV} / \mathrm{mm}$ [2] (the tunability is defined as Tun. $(\%)=(|\kappa(E)-\kappa(E=0)| / \kappa(E=0) \times 100)$. Various ferroelectric systems have been studied and, in recent years, work has been focused on the reduction of the dielectric loss of the materials, especially by combining, within a composite compound, the ferroelectric with a low-loss dielectric material $[3,4]$.

The current study concerns a new family of lead-free perovskite-based ferroelectric materials, with the formulation $\left(\mathrm{Sr}_{2} \mathrm{Ta}_{2} \mathrm{O}_{7}\right)_{100-\mathrm{x}}\left(\mathrm{La}_{2} \mathrm{Ti}_{2} \mathrm{O}_{7}\right)_{\mathrm{x}}$ (hereafter referred as STLT). Our work refers to undoped materials, not combined with a dielectric compound, and our objective is to highlight the dielectric and ferroelectric potential of these original materials in the radiofrequency range. It is the statement of a more complete study in the microwave range in view of integrating the materials in telecommunicating agile devices.

The STLT system combines two $n=4$ members of the layered perovskite $A_{n} B_{n} X_{3 n+2}$ series [5]: $\operatorname{Sr}_{2} \operatorname{Ta}_{2} \mathrm{O}_{7}\left(\mathrm{ST}_{)}\right)$and $\mathrm{La}_{2} \mathrm{Ti}_{2} \mathrm{O}_{7}$ (LT). Cross-substitution of $\mathrm{La}^{3+}$ for $\mathrm{Sr}^{2+}$ and $\mathrm{Ti}^{4+}$ for $\mathrm{Ta}^{5+}$ enables the charge compensation between cations and ensures the electroneutrality of the compounds. ST and LT are ferroelectric, with dissimilar Curie temperatures $\left(\mathrm{T}_{\mathrm{C}}\right)$, respectively $-105^{\circ} \mathrm{C}$ and $1461^{\circ} \mathrm{C}$ [6-7]. All these conditions met the requirements for the formation of a solid solution between ST and LT, thus offering the possibility of controlling the properties of the synthesized materials. A long time ago, Nanamatsu et al. demonstrated the variation of the Curie temperature of $\left(\mathrm{Sr}_{2} \mathrm{Ta}_{2} \mathrm{O}_{7}\right)_{100-\mathrm{x}}\left(\mathrm{La}_{2} \mathrm{Ti}_{2} \mathrm{O}_{7}\right)_{\mathrm{x}}$ compounds with the chemical composition $\mathrm{x}$ in the range $0-100$ [8]. The ferroelectric behavior of the two end members, $\mathrm{Sr}_{2} \mathrm{Ta}_{2} \mathrm{O}_{7}$ and $\mathrm{La}_{2} \mathrm{Ti}_{2} \mathrm{O}_{7}$, was proved by hysteresis loops of the polarization versus electric field (P-E curves), but no data were given for the solid solution compositions. To our knowledge, no further studies have been reported on the STLT system. 
The present study aims to reexamine the $\left(\mathrm{Sr}_{2} \mathrm{Ta}_{2} \mathrm{O}_{7}\right)_{100-\mathrm{x}}\left(\mathrm{La}_{2} \mathrm{Ti}_{2} \mathrm{O}_{7}\right)_{\mathrm{x}}$ ceramic system, by performing a complete dielectric and ferroelectric characterization in the radio-frequency range, including, for the first time, $\kappa-\mathrm{E}$ (permittivity-electric field) measurements. We are dealing with STLT ceramics with composition $\mathrm{x}$ ranging from 0 to 5; our goal is to determine which compositions ( $\mathrm{x}$ ) lead to a value of $\mathrm{T}_{\mathrm{C}}$ close to $\mathrm{RT}$, in order to benefit from a maximum tunability. We will compare our results to those obtained on standard ferroelectrics, for example $\mathrm{Ba}_{1-\mathrm{x}} \mathrm{Sr}_{\mathrm{x}} \mathrm{TiO}_{3}[3,4]$, as well as isotype layered perovskite systems such as $(\mathrm{Sr}, \mathrm{La})_{2}(\mathrm{Ta}, \mathrm{Nb})_{2} \mathrm{O}_{7}$ ceramics [9] and $\mathrm{Sr}_{2}\left(\mathrm{Ta}_{1-\mathrm{x}} \mathrm{Nb}_{\mathrm{x}}\right)_{2} \mathrm{O}_{7}$ as single-crystals [10,11] and thin films [12-14]. The present work relies also on our previous studies concerning $\mathrm{La}_{2} \mathrm{Ti}_{2} \mathrm{O}_{7}$ in the form of ceramics [15] and thin films [16] and our first attempt to produce directly STLT films [17].

\section{Material and methods}

\subsection{Material synthesis}

$\left(\mathrm{Sr}_{2} \mathrm{Ta}_{2} \mathrm{O}_{7}\right)_{100-\mathrm{x}}\left(\mathrm{La}_{2} \mathrm{Ti}_{2} \mathrm{O}_{7}\right)_{\mathrm{x}}$ powders with composition (x) ranging from 0 to 5 (see details in Supporting Information Table $\mathrm{S} 1$ ) were prepared by solid state reaction using a two-step process. First, for each composition (x), stoichiometric amounts of high purity powders of $\mathrm{SrCO}_{3}, \mathrm{Ta}_{2} \mathrm{O}_{5}, \mathrm{La}_{2} \mathrm{O}_{3}$ and $\mathrm{TiO}_{2}$ were homogenized in isopropanol for $1 \mathrm{~h}$ in an agate mortar and dried in an oven at $110^{\circ} \mathrm{C}$. The obtained powder was pressed into a pellet using an uniaxial press, then calcined in air for $15 \mathrm{~h}$ at $1000^{\circ} \mathrm{C}$, milled and calcined again at $1400^{\circ} \mathrm{C}$ for $15 \mathrm{~h}$. The final product was checked by X-ray diffraction (XRD) for phase identification. Then, the powder was mixed with a rhodoviol solution (5 wt.\%) as a binder, pressed at $220 \mathrm{MPa}$ to form a pellet (12 or $18 \mathrm{~mm}$ in diameter and $0.5 \mathrm{~mm}$ thick) and subsequently sintered at $1500^{\circ} \mathrm{C}$ for $2 \mathrm{~h}$, by burying it or not in $\mathrm{Sr}_{2} \mathrm{Ta}_{2} \mathrm{O}_{7}$ powder placed in an alumina crucible.

\subsection{Structural characterization}

The phase structure of calcined powders and sintered ceramics was analyzed by XRD technique using, respectively, a Panalytical X'pert Pro diffractometer (Cu K-L2,3 radiation) and a Seifert 3003 PTS diffractometer (Cu K-L3 radiation). Lattice parameters for the different powder samples were estimated from Lebail-type profile fit carried out with the Fullprof program [18] and considering the Cmcm space group; the Pseudo-Voigt profile function was used and the background was approximated by linear interpolation between a set of background points. Energy Dispersive Spectrometry (EDS) was used to investigate the cations chemical composition of the STLT ceramics; analysis was performed using the Aztek OXFORD software through a JEOL JSM IT-100 scanning electron microscope (SEM) operating at $10 \mathrm{kV}$. The surface and fracture morphologies of ceramics were examined using the previous JEOL equipment.

\subsection{Dielectric and ferroelectric characterization}

For electrical properties measurements, gold electrodes were deposited through a rigid mask by dc sputtering on both faces of the pellets. The frequency and temperature dielectric spectra were measured using a LCR meter (LCR-819 GWInstek) in the $1 \mathrm{~Hz}-100 \mathrm{kHz}$ frequency range and temperature interval from $20^{\circ} \mathrm{C}$ to $300^{\circ} \mathrm{C}$. External DC voltages $(0-\max 200 \mathrm{~V}$, Keithley 2400) were applied through a Keysight 16065A voltage bias fixture to point out a variation of the relative permittivity (i.e. Tunability). Ferroelectric hysteresis P-E were characterized at room temperature ( $\mathrm{f}=50 \mathrm{~Hz}$ ) using a Sawyer-Tower circuit with a $68 \mathrm{nF}$ serial capacitor; a high voltage amplifier (Trek 609E-6, $0-5000 \mathrm{~V}$ ) was used to tune the amplitude of the applied electric field. I-E loops were also recorded; values of current were calculated from the polarization using the relation $\mathrm{I}=\mathrm{A} \mathrm{dP} / \mathrm{dt}$, where $\mathrm{A}$ is the electrode area.

\section{Results}

\subsection{Synthesis of powders}

Figure 1 shows the XRD patterns of the calcined $\left(\mathrm{Sr}_{2} \mathrm{Ta}_{2} \mathrm{O}_{7}\right)_{100-\mathrm{x}}\left(\mathrm{La}_{2} \mathrm{Ti}_{2} \mathrm{O}_{7}\right)_{\mathrm{x}}$ powders for $\mathrm{x}$ ranging from 0 to 5 . Given the small content of $\mathrm{La}_{2} \mathrm{Ti}_{2} \mathrm{O}_{7}$ in the synthesized STLT powders, diffraction peaks of all the samples were found to match either those of the JCPDS File No. 70-0248 (space group Cmcm) or the No. 72-0921 (space group Cmc2 ${ }_{1}$ ) of $\mathrm{Sr}_{2} \mathrm{Ta}_{2} \mathrm{O}_{7}$. These two space groups are associated to the paraelectric state and ferroelectric state of $\mathrm{Sr}_{2} \mathrm{Ta}_{2} \mathrm{O}_{7}$ respectively and are nearly undiscernible, as discussed later. 
To further evaluate the variation of the crystal structure, lattice parameters and cell volume were calculated (data are gathered in Table S1) and plotted as a function of the composition (x) in Figure 2. Both parameters $a$ (Figure 2a) and $c$ (Figure $2 \mathrm{c}$ ) slightly vary with $\mathrm{x}$ whereas $b$ (Figure $2 \mathrm{~b}$ ) significantly decreases. The resulting cell volume (Figure $2 \mathrm{~d}$ ) decreases. These evolutions are due to the ionic radii difference on the $\mathrm{A}$ and $\mathrm{B}$ sub-lattices of the $\mathrm{A}_{2} \mathrm{~B}_{2} \mathrm{O}_{7}$ perovskite-type structure $\left(\left(\mathrm{Sr}^{2+}, \mathrm{r}=\right.\right.$ $1.44 \AA$, coord. 12); $\left(\mathrm{Ta}^{5+}, \mathrm{r}=0.64 \AA\right.$, coord.6) vs. $\left(\mathrm{La}^{3+}, \mathrm{r}=1.36 \AA\right.$, coord. 12); ( $\mathrm{Ti}^{4+}, \mathrm{r}=0.60 \AA$, coord. 6)) [19]. Finally, it should be noted that the evolution of the lattice parameters and the cell volume is linear following a Vegard's law, demonstrating the formation of an ideal solid solution in the composition range $0 \leq \mathrm{x} \leq 5$. This result is similar to that of Kato et al. which have worked on the $\mathrm{Sr}_{2}\left(\mathrm{Ta}_{1-\mathrm{x}} \mathrm{Nb}_{\mathrm{x}}\right)_{2} \mathrm{O}_{7}$ solid solution prepared by conventional solid state reactions [20] $\left(\operatorname{the~} \mathrm{Sr}_{2} \mathrm{Nb}_{2} \mathrm{O}_{7}\right.$ compound has a $\mathrm{T}_{\mathrm{C}}\left(1342^{\circ} \mathrm{C}\right)$ comparable to $\mathrm{La}_{2} \mathrm{Ti}_{2} \mathrm{O}_{7}$ studied here).

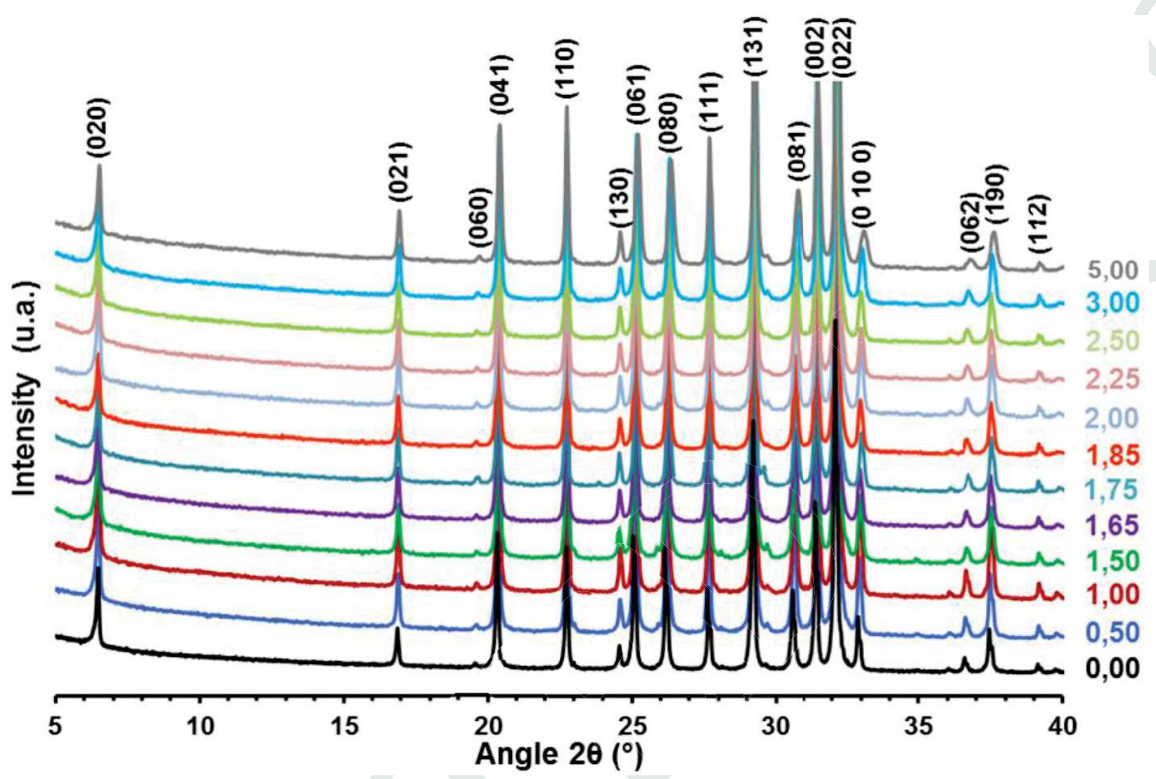

Figure 1. $\theta-2 \theta$ X-ray diagrams of the $\left(\mathrm{Sr}_{2} \mathrm{Ta}_{2} \mathrm{O}_{7}\right)_{100-\mathrm{x}}\left(\mathrm{La}_{2} \mathrm{Ti}_{2} \mathrm{O}_{7}\right)_{\mathrm{x}}$ powders with $0 \leq \mathrm{x} \leq 5$, synthesized by solid state route. Diffraction peaks are indexed according to an isotype of the paraelectric $\mathrm{Sr}_{2} \mathrm{Ta}_{2} \mathrm{O}_{7}$ compound (JCPDS File No.70-0248).
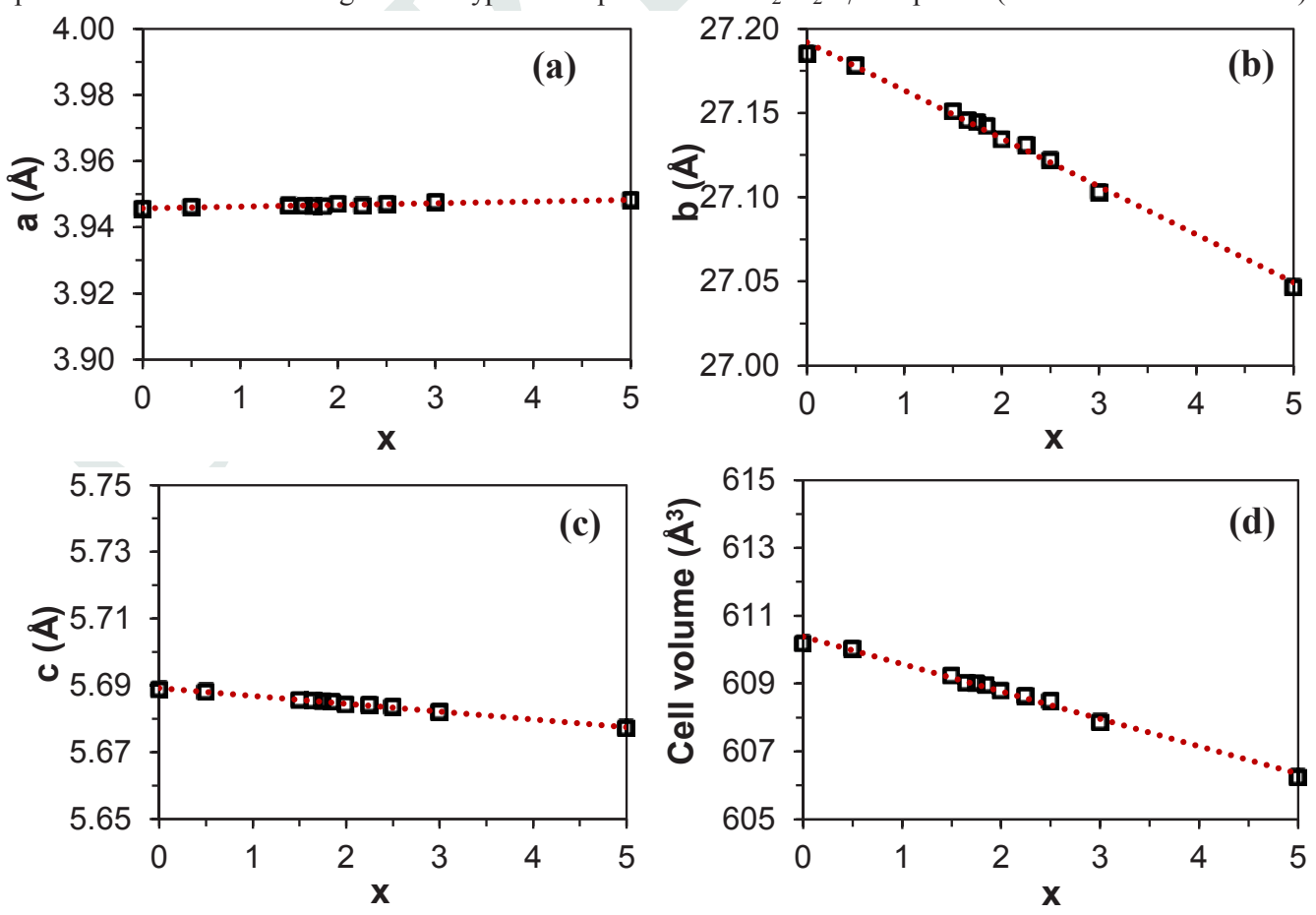

Figure 2. Evolution as a function of the composition (x) of: (a)(b)(c) cell parameters and (d) cell volume of $\left(\operatorname{Sr}_{2} \mathrm{Ta}_{2} \mathrm{O}_{7}\right)_{100-\mathrm{x}}\left(\mathrm{La}_{2} \mathrm{Ti}_{2} \mathrm{O}_{7}\right) \mathrm{x}$ powders synthesized by solid state route (the uncertainty on each value is always less than the height of the drawn symbol). 


\subsection{Microstructure and phase composition of ceramics}

Figure 3 shows the XRD patterns of each face of two ceramic samples with the same composition $(x=3)$, sintered with and without the use of $\mathrm{Sr}_{2} \mathrm{Ta}_{2} \mathrm{O}_{7}$ powder. Without the powder (Figure 3b), we notice that the upper face of the pellet corresponds to the desired $\mathrm{Sr}_{2} \mathrm{Ta}_{2} \mathrm{O}_{7}$ phase, whereas the lower face (in contact with the alumina pan) is mainly composed of the strontium-deficient $\mathrm{SrTa}_{4} \mathrm{O}_{11}$ phase (JCPDS No. 63-0608). This is confirmed by the EDS composition analysis: the $\mathrm{Sr} / \mathrm{Ta}$ ratio is 1.00 and 0.70 for the top face and bottom face, respectively. The pellet sintered with the powder (Figure 3a) presents the unique $\mathrm{Sr}_{2} \mathrm{Ta}_{2} \mathrm{O}_{7}$ phase on its two faces thus demonstrating that the use of the powder, i.e. no surface of the pellet directly in contact with the alumina plate, has prevented the diffusion of strontium during the sintering at high temperature $\left(1500^{\circ} \mathrm{C}\right)$. EDS analysis confirms this, with a $\mathrm{Sr} / \mathrm{Ta}$ ratio of 0.95 for the top and bottom faces. In the balance of this section, as a consequence, all the STLT pellets were sintered using $\mathrm{Sr}_{2} \mathrm{Ta}_{2} \mathrm{O}_{7}$ powder in the alumina crucible.

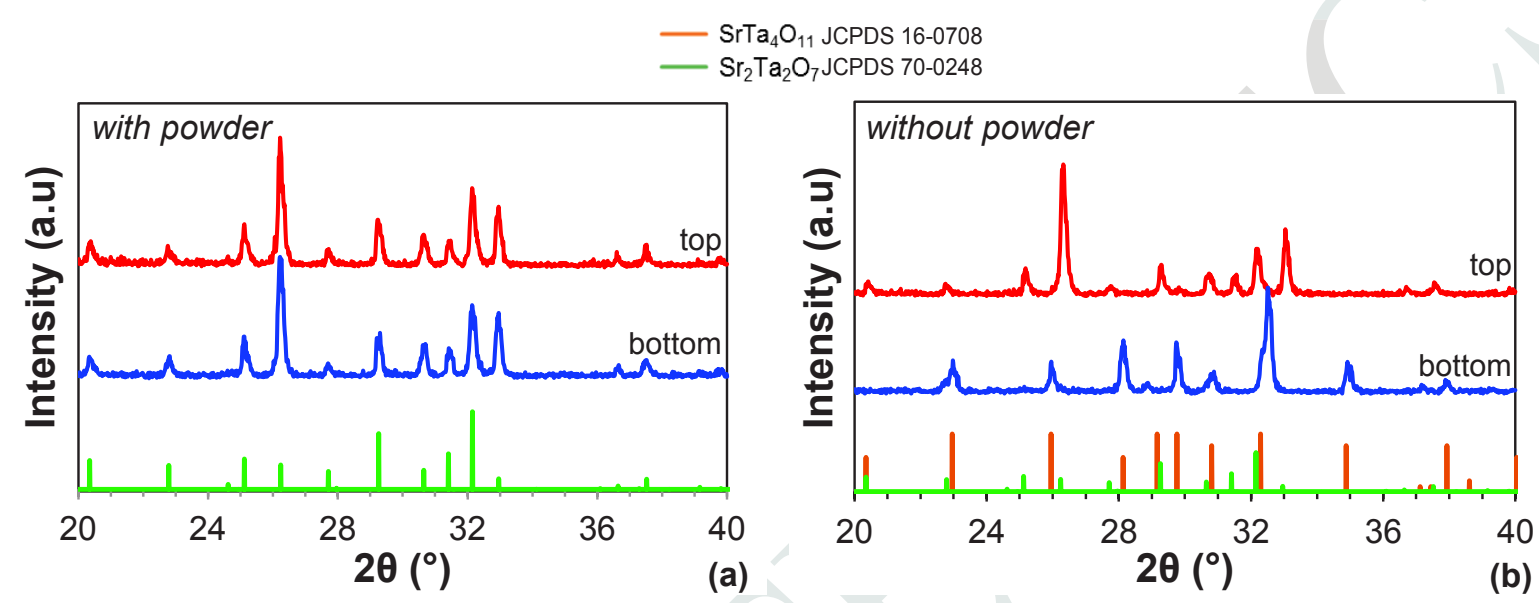

Figure 3. $\theta-2 \theta \mathrm{X}$-ray diagrams of the top and bottom faces of $\left(\mathrm{Sr}_{2} \mathrm{Ta}_{2} \mathrm{O}_{7}\right)_{100-\mathrm{x}}\left(\mathrm{La}_{2} \mathrm{Ti}_{2} \mathrm{O}_{7}\right)_{\mathrm{x}}$ ceramics with composition $\mathrm{x}=3$ sintered at $1500^{\circ} \mathrm{C}$ with (a) and without (b) $\mathrm{Sr}_{2} \mathrm{Ta}_{2} \mathrm{O}_{7}$ powder in the alumina crucible.

The surface microstructures of some STLT ceramics are shown in Figure 4 (the photos of all the synthesized ceramics are given in Figure S3). First, it can be observed that the grains are densely packed on each other with rounded platelet-like shapes; a certain amount of rather isolated intergranular pores are randomly dispersed in the bulk. Secondly, except for $\mathrm{x}=0$, the grain sizes of ceramics are similar, in the range $2-5 \mu \mathrm{m}$. $\mathrm{The} \mathrm{Sr}_{2} \mathrm{Ta}_{2} \mathrm{O}_{7}$ sample $(\mathrm{x}=0)$ shows a large dispersion of the grain size, from few microns to several tens of microns, characteristic of abnormal grain growth at high temperature. These observations suggest that even a tiny addition of $\mathrm{La}_{2} \mathrm{Ti}_{2} \mathrm{O}_{7}$ to $\mathrm{Sr}_{2} \mathrm{Ta}_{2} \mathrm{O}_{7}$ allows a homogeneous growth of grains. As pointed out by many studies [21], this is an important feature since grain size strongly affects the dielectric and ferroelectric properties of ceramics. The fracture microstructures seen in Figure 4 confirm the observations made on the surface, namely, platelet grains, the presence of a closed porosity and similar grain sizes except for the composition $\mathrm{x}=0$ which exhibits very large grains. As shown in Table S2, the relative densities of the ceramics are in the range $81-98 \%$ of the theoretical density of STLT that is in good agreement with the above SEM pictures. 

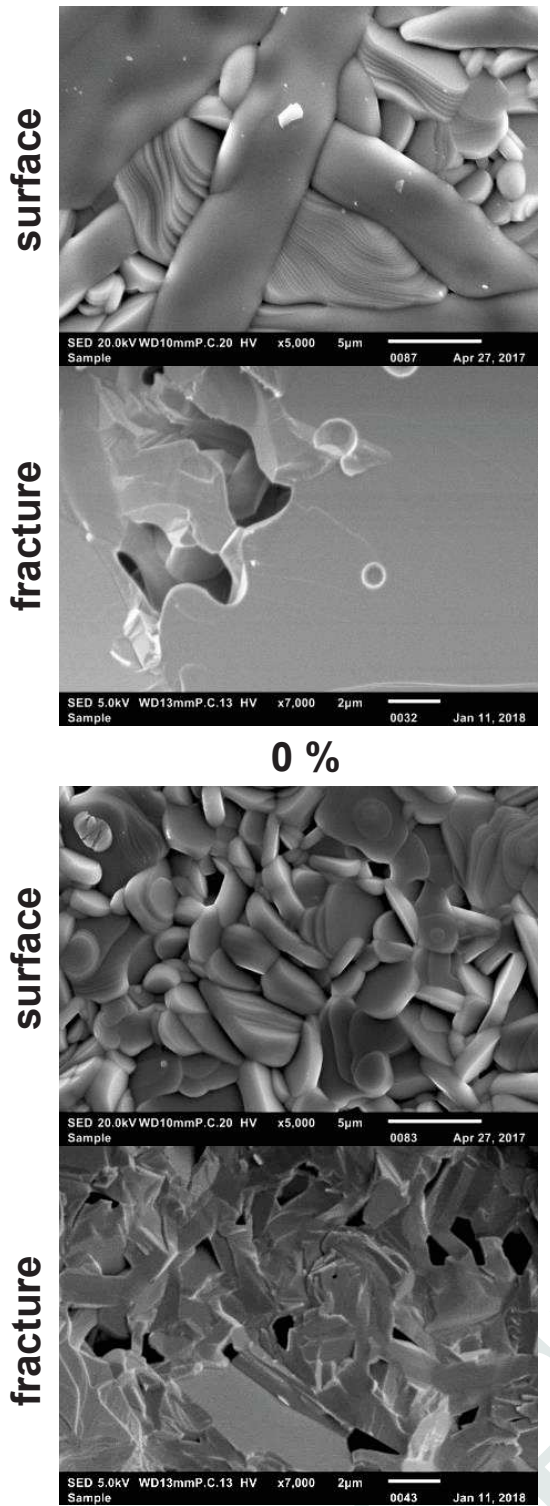

$2.0 \%$

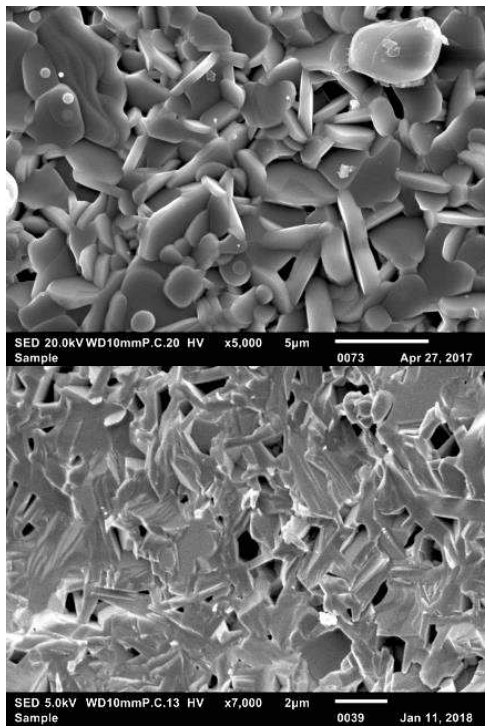

$1.65 \%$

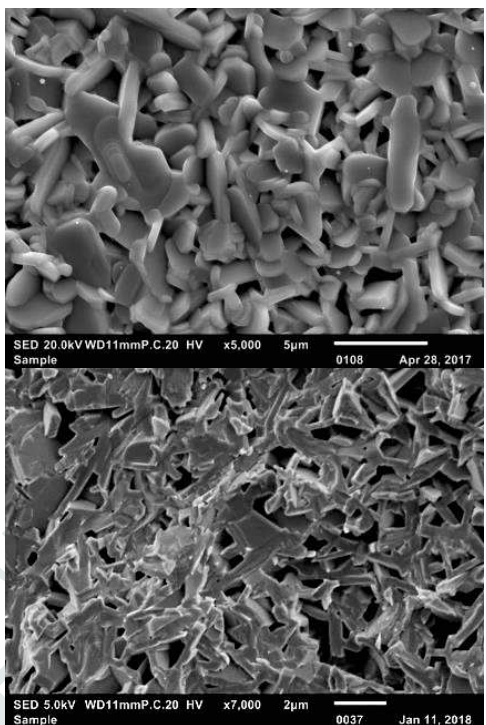

$2.5 \%$

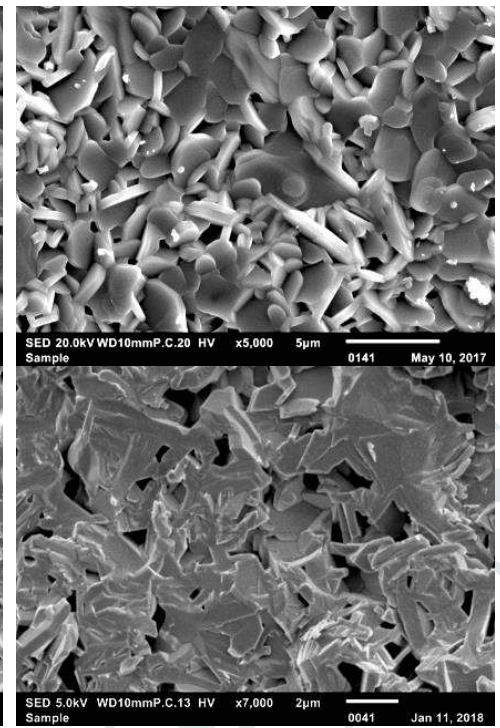

$1.85 \%$

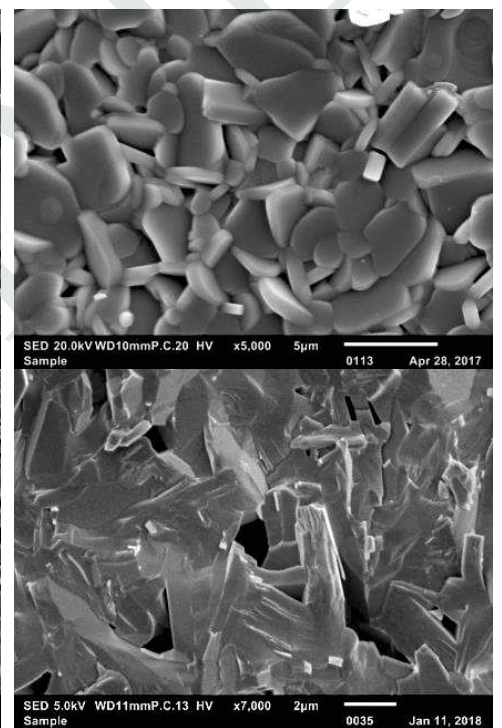

$3.0 \%$

Figure 4. Scanning electron microscopy surface and fracture morphologies of some $\left(\operatorname{Sr}_{2} \mathrm{Ta}_{2} \mathrm{O}_{7}\right)_{100-\mathrm{x}}\left(\mathrm{La}_{2} \mathrm{Ti}_{2} \mathrm{O}_{7}\right)_{\mathrm{x}}$ ceramics sintered at $1500^{\circ} \mathrm{C}$ (the composition $\mathrm{x}$ is given below the micrographs).

\subsection{Dielectric and ferroelectric properties}

The evolution of the relative permittivity $(\kappa)$ and dielectric losses $(\tan \delta)$ at room temperature as a function of the frequency for all the STLT ceramics is presented in Figure 5. $\kappa$ and tan $\delta$ vary slightly with frequency, with no observable relaxation or resonance.

Figure 6 exhibits the dependence of the relative permittivity and dielectric losses on the composition (x) at $10 \mathrm{kHz}$. It shows at RT a maximum value of the relative permittivity $(\kappa=365)$ for $x=1.65$. Indeed, permittivity values are higher than 300 for compositions in the range $1.5-2.5$. Additionally, low dielectric loss tangent values, i.e. less than 0.01 , are found for the compositions $\mathrm{x} \leq 1.65$.

No permittivity data of STLT compounds are available in literature, but our values can be compared with those of similar layered perovskites such as $\mathrm{Sr}_{2}\left(\mathrm{Nb}_{\mathrm{x}} \mathrm{Ta}_{1-\mathrm{x}}\right)_{2} \mathrm{O}_{7}$ [11]: $\kappa$ was in the range $600-800$ for $\mathrm{x}=1-8 \%$ (@RT,100 kHz). These values measured on single crystals are somewhat higher than the ones we have determined on moderately densified polycrystal- 
line ceramics. Concerning $\mathrm{Sr}_{2} \mathrm{Ta}_{2} \mathrm{O}_{7}(\mathrm{x}=0)$, our relative permittivity value $\kappa=110(10 \mathrm{kHz})$ is very close to the value $\kappa \sim$ $105(1 \mathrm{kHz})$ obtained on ceramics by Isupov et al. [5]; it is slightly higher than $\kappa \sim 85$ at $15 \mathrm{kHz}$ reported on $\mathrm{Sr}_{2} \mathrm{Ta}_{2} \mathrm{O}_{7}$ singlecrystals by Hushur et al. [6] and $\kappa=76$ at $10 \mathrm{kHz}$ reported on ceramics by Y-J. Song et al. [22].
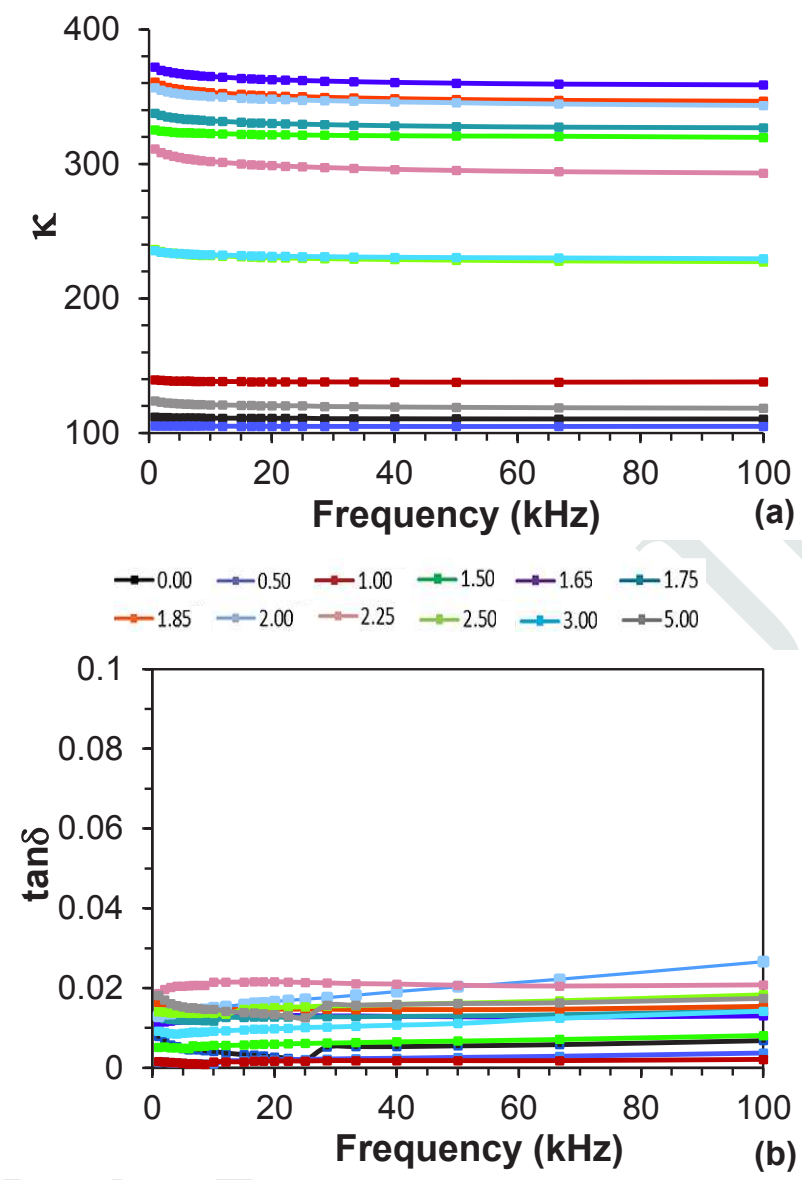

Figure 5. Evolution as a function of frequency and for different compositions ( $\mathrm{x}$ ) of: (a) the relative permittivity ( $\kappa$ ) and (b) the dielectric losses $(\tan \delta)$ of $\left(\mathrm{Sr}_{2} \mathrm{Ta}_{2} \mathrm{O}_{7}\right)_{100-\mathrm{x}}\left(\mathrm{La}_{2} \mathrm{Ti}_{2} \mathrm{O}_{7}\right)_{\mathrm{x}}$ ceramics with $0 \leq \mathrm{x} \leq 5$ (measurements made at $\mathrm{RT}$ ).

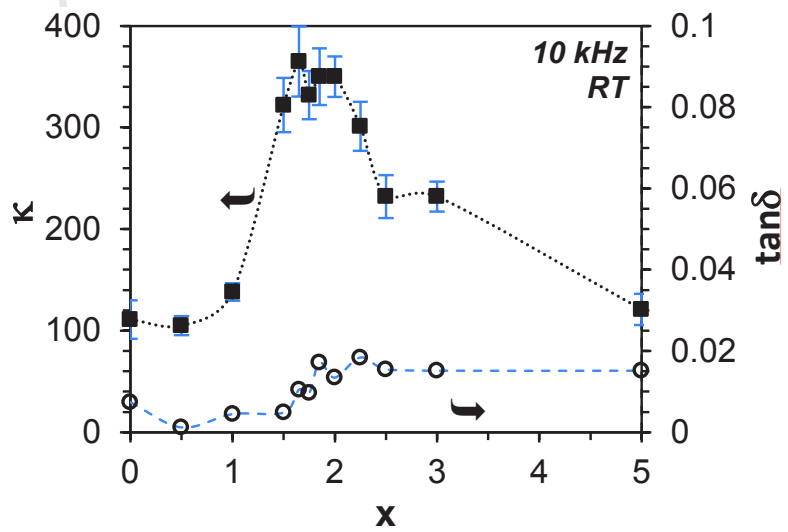

Figure 6. Evolution of the relative permittivity $(\kappa)$ and dielectric losses $(\tan \delta)$ as a function of the composition $(\mathrm{x})$ of $\left(\mathrm{Sr}_{2} \mathrm{Ta}_{2} \mathrm{O}_{7}\right)_{100-}$ ${ }_{\mathrm{x}}\left(\mathrm{La}_{2} \mathrm{Ti}_{2} \mathrm{O}_{7}\right)_{\mathrm{x}}$ ceramics. 
Evolution of $\kappa$ as a function of the temperature at $10 \mathrm{kHz}$ is given in Figure 7 . We clearly observe the existence of maxima of the relative permittivity above RT for the compositions $\mathrm{x} \geq 1.85$. It is also noticed that the permittivity maximum shifts towards higher temperatures as the $\mathrm{La}_{2} \mathrm{Ti}_{2} \mathrm{O}_{7}$ content (x) increases, as can be seen from the insert (Figure 7) representing the evolution of the temperature maximum $\left(\mathrm{T}_{\mathrm{M}}\right)$ as a function of the composition $\left(\mathrm{T}_{\mathrm{M}}\right.$ is defined as the temperature of the maximum of the relative permittivity). The compositions $\mathrm{x}=1.65$ and 1.75 have $\mathrm{T}_{\mathrm{M}}$ values very close to ambient temperature. A second weak maximum can be observed for some compositions at around $200^{\circ} \mathrm{C}$. One first explanation could be a phase transition of the material around this temperature, but this is not supported by the XRD measurements we performed as a function of temperature on the $\mathrm{x}=3.0$ sample (see later in Discussion). Secondly, it could come from extrinsic defects (generated during the same protocol of synthesis and sintering), giving rise, for example, to an electronic conduction [23]; these defects would be activated as temperature increases.

The present $\mathrm{T}_{\mathrm{M}}$ evolution is consistent with the one reported by Nanamatsu et al. on these STLT materials [8]. It is also consistent with the one obtained on a $\mathrm{Sr}_{1.98} \mathrm{La}_{0.02} \mathrm{Ta}_{1.9} \mathrm{Nb}_{0.1} \mathrm{O}_{7}$ ceramic [9] and with those concerning $\mathrm{Sr}_{2}\left(\mathrm{Nb}_{\mathrm{x}} \mathrm{Ta}_{1-\mathrm{x}}\right)_{2} \mathrm{O}_{7}$ singlecrystals exhibiting a variation of $\mathrm{T}_{\mathrm{C}}$ from $-68^{\circ} \mathrm{C}$ for $\mathrm{x}=1 \%$ to $207^{\circ} \mathrm{C}$ for $\mathrm{x}=8 \%$ [11].

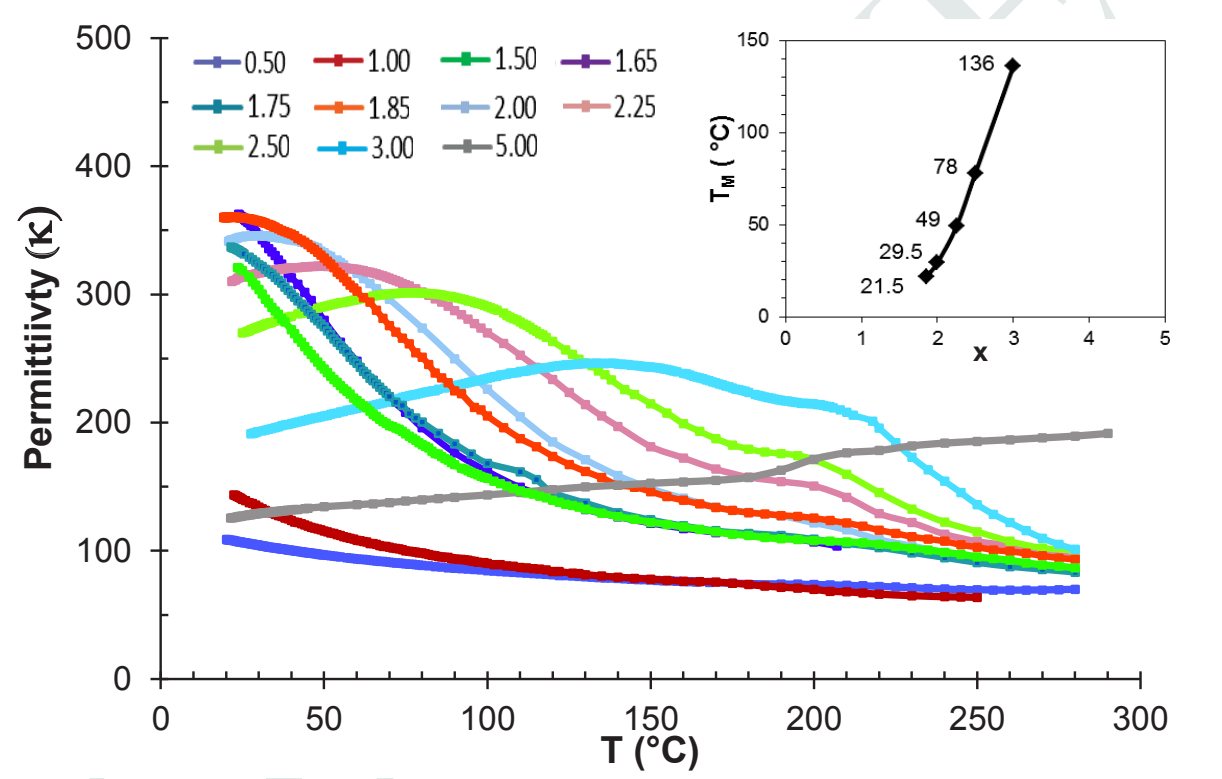

Figure 7. Evolution as a function of the temperature of the relative permittivity $(\kappa)$ of $\left(\operatorname{Sr}_{2} \mathrm{Ta}_{2} \mathrm{O}_{7}\right)_{100-\mathrm{x}}\left(\mathrm{La}_{2} \mathrm{Ti}_{2} \mathrm{O}_{7}\right)_{\mathrm{x}}$ ceramics with $0 \leq \mathrm{x} \leq 5$ (in insert, is plotted the evolution of the maximum temperature $\left(\mathrm{T}_{\mathrm{M}}\right)$ as a function of the composition $\mathrm{x}$ ).

Ceramic samples have been characterized by P-E measurements at room temperature and $50 \mathrm{~Hz}$; some curves are presented in Figure 8. A linear evolution of $\mathrm{P}$ is featured for the composition $\mathrm{x}=0$, while $\mathrm{x}=1.65$ exhibits a non-linear and nonopen curve. P-E hysteresis loops are clearly observed for the compositions $\mathrm{x}=1.85,2.0,2.5$ and 3.0. We note that the hysteresis loop for $\mathrm{x}=2.0$ is slim and nearly saturated; it could be related to a higher quality of this sample, also evidenced in tunability measurements presented thereafter. Figure 8 also gives the current-electric field (I-E) curves of the studied compositions. The $\mathrm{x}=1.65$ sample presents weak current peaks close to $0 \mathrm{kV} / \mathrm{cm}$; this could indicate that this composition is nearly at its ferroelectric-paraelectric transition at RT. For $x \geq 1.85$, two switching current peaks near the coercive electric fields are clearly seen that confirm the existence of a long-range ferroelectric order for these compositions.

Figure 9 presents the evolution of the tunability as a function of the composition (x) of STLT samples. The frequency 1 $\mathrm{kHz}$ has been chosen because, for higher frequencies, dielectric losses of the $\mathrm{x}=1.65$ sample are too low to be measured by our equipment. No tunability is measured for the compositions $0 \leq \mathrm{x} \leq 1$; for $\mathrm{x}=0$, this is in accordance with its linear P-E curve. Tunability is observed for $\mathrm{x} \geq 1.5$; a maximum value is reached for $\mathrm{x}=1.65$. Figure 10 features the evolution of the permittivity as a function of a DC electric field up to $0.36 \mathrm{kV} / \mathrm{mm}$ for the STLT ceramics. No variation is seen for $\mathrm{x}=0$ while non-linear curves are observed for compositions with $1.65 \leq \mathrm{x} \leq 2.00$, with a noticeable butterfly shape for $\mathrm{x}=2.00$. 
High tunabilities, $17.4 \%$ and $17.0 \%$, are observed for $\mathrm{x}=1.65$ and $\mathrm{x}=2.00$ respectively $(@ 0.36 \mathrm{kV} / \mathrm{mm})$. Compositions $\mathrm{x}=$ 2.50 and 3.00 present quasi-linear evolutions of $\kappa$.

For the composition $\mathrm{x}=1.65$ (Figure 11 ), dielectric losses are very low and evolve from $2.10^{-3}$ at $0 \mathrm{kV} / \mathrm{mm}$ to lower than $2.10^{-4}$ when electric field is applied. Evolution of $\kappa$ at $10 \mathrm{kHz}$ and $100 \mathrm{kHz}$ is given in Figure S4. Tunability is stable, from $18.1 \%$ at $1 \mathrm{kHz}$ to $17.6 \%$ at $10 \mathrm{kHz}$ and $17.4 \%$ at $100 \mathrm{kHz}(@ 0.38 \mathrm{kV} / \mathrm{mm})$, with $\tan \delta$ always lower than $2.10^{-3}$.
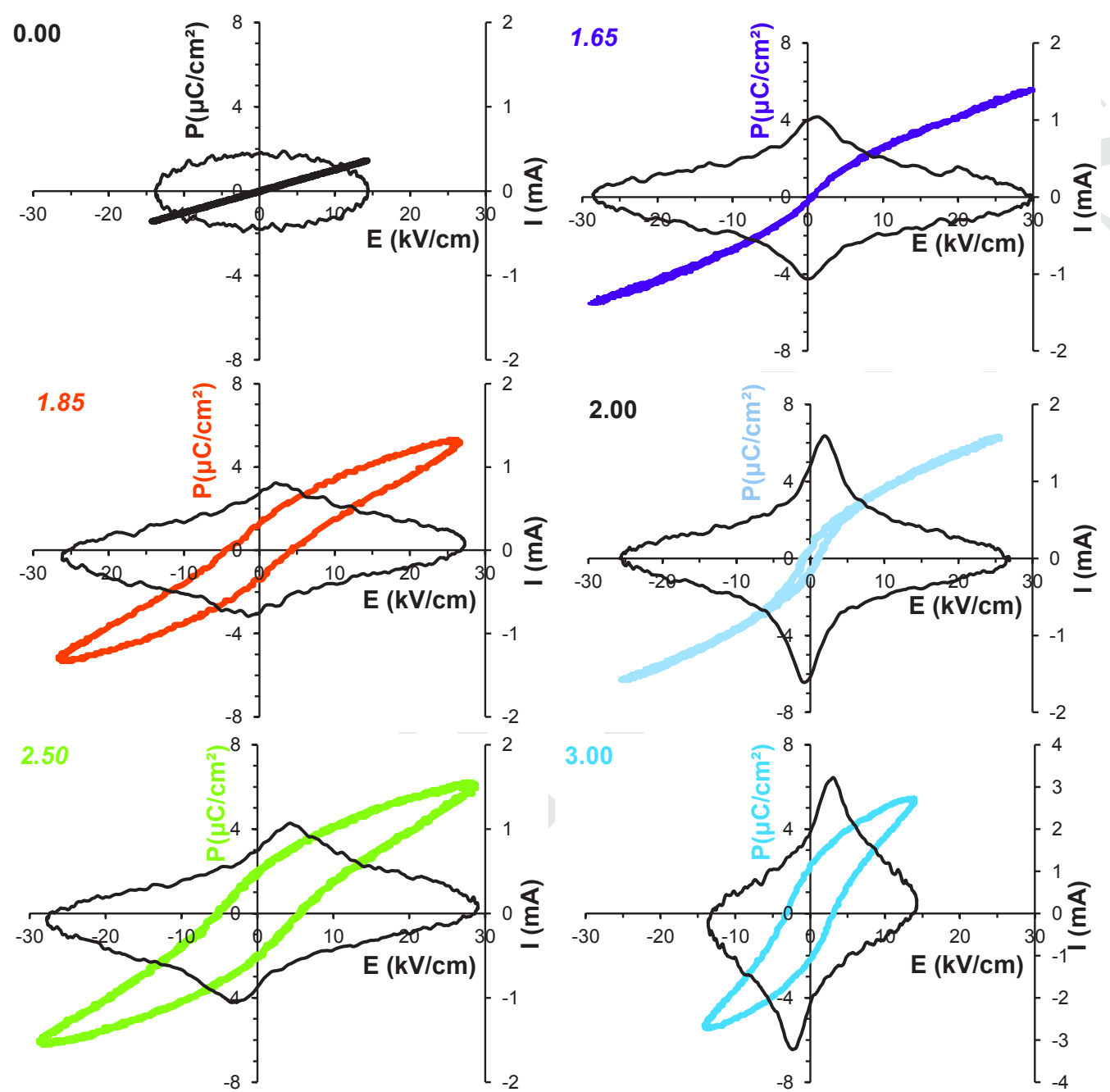

Figure 8. Polarization-Electric field (P-E) (in color) and current-Electric field (I-E) (in black) curves of $\left(\mathrm{Sr}_{2} \mathrm{Ta}_{2} \mathrm{O}_{7}\right)_{100-\mathrm{x}}\left(\mathrm{La}_{2} \mathrm{Ti}_{2} \mathrm{O}_{7}\right)_{\mathrm{x}}$ ceramics (the composition x is given in insert; measurements were made @ $50 \mathrm{~Hz}, \mathrm{RT}$ ).

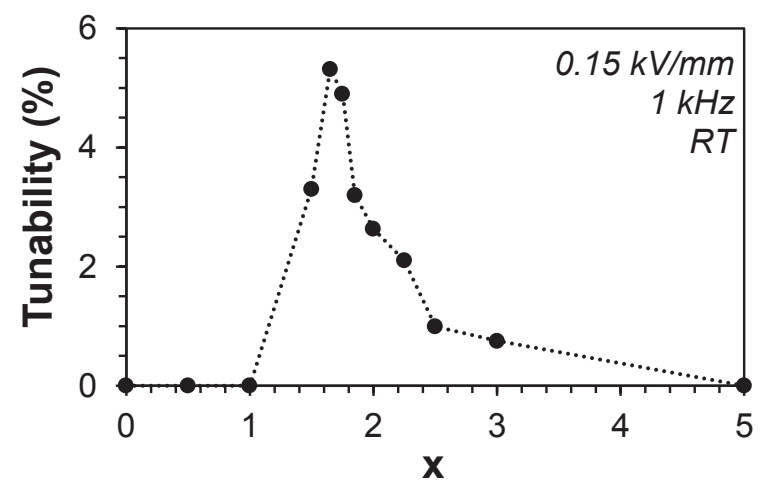

Figure 9. Evolution of the tunability as a function of the composition $(\mathrm{x})$ of $\left(\mathrm{Sr}_{2} \mathrm{Ta}_{2} \mathrm{O}_{7}\right)_{100-\mathrm{x}}\left(\mathrm{La}_{2} \mathrm{Ti}_{2} \mathrm{O}_{7}\right)_{\mathrm{x}}$ ceramics. 


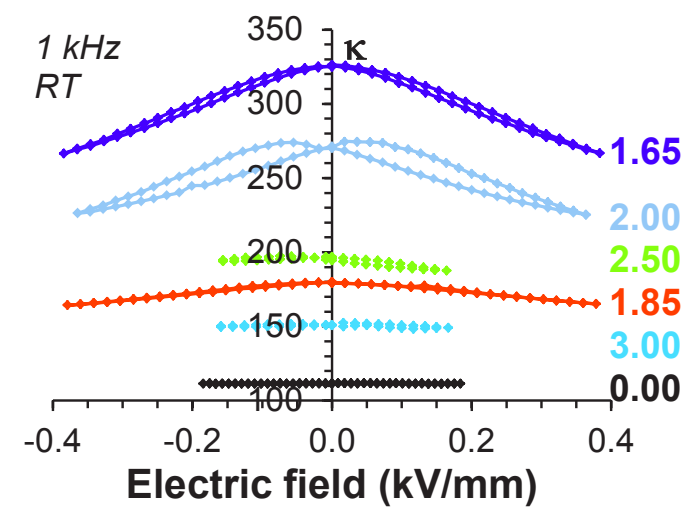

Figure 10. Evolution as a function of a DC electric field of the relative permittivity $(\kappa)$ of $\left(\mathrm{Sr}_{2} \mathrm{Ta}_{2} \mathrm{O}_{7}\right)_{100-\mathrm{x}}\left(\mathrm{La}_{2} \mathrm{Ti}_{2} \mathrm{O}_{7}\right)_{\mathrm{x}}$ ceramics with composition $\mathrm{x}=0,1.65,1.85,2.00,2.50$ and 3.00 .

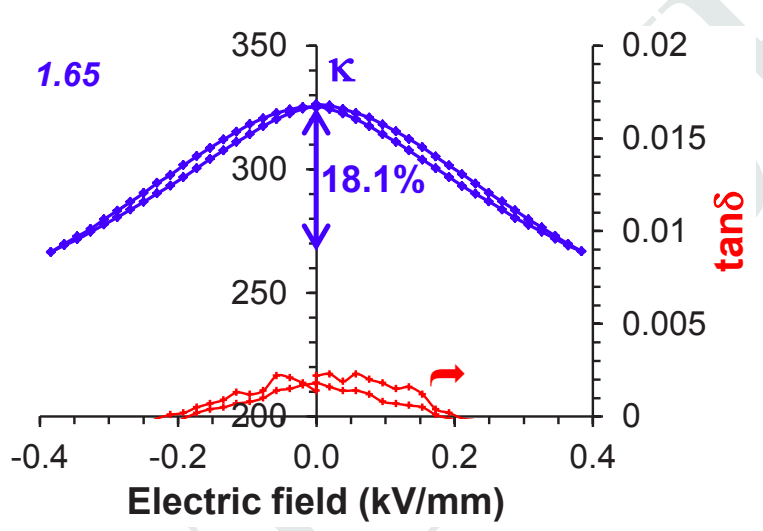

Figure 11. Evolution as a function of a DC electric field of the relative permittivity $(\kappa)$ and dielectric loss $(\tan \delta)$ of the $\mathrm{x}=1.65$ $\left(\mathrm{Sr}_{2} \mathrm{Ta}_{2} \mathrm{O}_{7}\right)_{100-\mathrm{x}}\left(\mathrm{La}_{2} \mathrm{Ti}_{2} \mathrm{O}_{7}\right)_{\mathrm{x}}$ ceramic (measurements made @ $\left.1 \mathrm{kHz}, \mathrm{RT}\right)$.

\section{Discussion}

The $\left(\mathrm{Sr}_{2} \mathrm{Ta}_{2} \mathrm{O}_{7}\right)_{100-\mathrm{x}}\left(\mathrm{La}_{2} \mathrm{Ti}_{2} \mathrm{O}_{7}\right)_{\mathrm{x}}$ layered perovskite system has not been reported since the study of Nanamatsu et al. [8]. The aim of the present study is to fully characterize its dielectric and ferroelectric properties.

Within the explored $0-5$ composition range, we have evidenced a continuous solid solution domain with cell parameters and volume varying linearly with $\mathrm{x}$. In order to clarify the identification of the STLT materials to the paraelectric (space group $\mathrm{Cmcm}$ ) or ferroelectric (space group $\mathrm{Cmc}_{1}$ ) $\mathrm{Sr}_{2} \mathrm{Ta}_{2} \mathrm{O}_{7}$ phase, additional XRD analyses were performed as a function of temperature on a sample $(\mathrm{x}=3.0)$ suspected to show a phase transition in the $25^{\circ} \mathrm{C}$ to $300^{\circ} \mathrm{C}$ range (see diffractogram in Figure S5). As reported by Ishizawa et al. on single crystals of the isotype $\mathrm{Sr}_{2}\left(\mathrm{Ta}_{1-\mathrm{x}} \mathrm{Nb}_{\mathrm{x}}\right)_{2} \mathrm{O}_{7}$ system [24], Cmcm and $\mathrm{Cmc} 2_{1}$ structure types are very close with only the loss of a mirror plane related to a displacement of the metal atoms along the $c$ axis and a slight rotation of the $(\mathrm{Ta}, \mathrm{Nb}) \mathrm{O}_{6}$ octahedral along the $a$ axis leading to a reduction of the symmetry from $\mathrm{Cmcm}$ to $\mathrm{Cmc} 2_{1}$ and the appearance of the ferroelectric behavior at low temperature. The authors pointed out the difficulty to differentiate both structure types from single crystal data as refinements performed using both space groups of each sample lead to very close $\mathrm{R}$ factor values. The only noticeable difference was a change in behavior regarding the temperature dependence of the thermal parameters of the A and B site cations in the two crystal phases of $\operatorname{Sr}_{2}\left(\mathrm{Ta}_{1-\mathrm{x}} \mathrm{Nb}_{\mathrm{x}}\right)_{2} \mathrm{O}_{7}$, i.e. paraelectric and ferroelectric, at a temperature corresponding to $\mathrm{T}_{\mathrm{C}}$. In our case, on powders, no noticeable difference is seen in the XRD diagrams performed in temperature. Indeed, the Rietveld refinements considering both space groups do not allow us to differentiate experimentally the two cells and so, to unambiguously identify the type of the $\operatorname{Sr}_{2} \mathrm{Ta}_{2} \mathrm{O}_{7}$ phase present in each synthesized STLT material.

The similarity between the two structures has another consequence: it could be responsible for the moderate permittivity values of the STLT ceramics. Indeed, the maximum relative permittivity value attained in our study is $\kappa=365$ (@10 kHz) 
for the composition $\mathrm{x}=1.65$, while permittivities of several thousands are commonly obtained in standard ferroelectrics, for example, in $\mathrm{Ba}_{1-\mathrm{x}} \mathrm{Sr}_{\mathrm{x}} \mathrm{TiO}_{3}$ [25]. The latter compound is characterized by large off-center displacements of the metal ions [26] and is hereby named as a displacive-type ferroelectric. As pointed out by Ishizawa et al. [24], the difference in the atomic coordinates between the ferroelectric and the paraelectric cells of $\mathrm{Sr}_{2} \mathrm{Ta}_{2} \mathrm{O}_{7}$ are small, with moderate displacements of the metal ions as also noticed by Ok et al. [26]. These, associated with a distortion of the $\mathrm{O}_{6}$ octahedral at the ferroelectricparaelectric transition, could be the sign of an improper, topological-type ferroelectricity of the STLT layered perovskite oxide, as suggested by Lopez-Perez et al. for the parent $\mathrm{La}_{2} \mathrm{Ti}_{2} \mathrm{O}_{7}$ layered perovskite material [27]. The consequence would

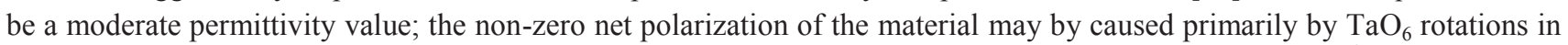
the perovskite layered structure.

In the present study, P-E and I-E experiments demonstrate the ferroelectric behavior at RT of the STLT materials with composition $\mathrm{x}=1.85,2.0,2.5$ and 3.0, with clear hysteresis cycles and switching current peaks. In accordance with the $\mathrm{T}_{\mathrm{M}}$ values determined from the temperature dielectric curves, it confirms that these STLT materials are in their ferroelectric states at RT. However, tunabilities obtained for $\mathrm{x}=2.50$ and 3.00 samples are very low and can be due to the fact that these compositions are positioned far from their transition temperature at ambient temperature. At the contrary, features obtained for $\mathrm{x}=1.65$ suggest that this composition is almost at the ferroelectric - paraelectric transition at RT. Moreover, the different characterization we made show that the best quality samples within the synthesized series are those with compositions $\mathrm{x}=$ 1.65 and 2.00. The latter exhibits an almost saturated hysteresis P-E loop and has a high tunability with a marked $\kappa$-E butterfly shape characteristic of a ferroelectric material. The $\mathrm{x}=1.65$ sample presents the best properties combining a high tunability (Tun.=18.1\%@1 kHz) for a low applied electric field value $(0.38 \mathrm{kV} / \mathrm{mm})$ along with very low dielectric losses $(\tan \delta=$ $2.10^{-3}$ at $\mathrm{E}=0 \mathrm{kV} / \mathrm{cm}$ and $\tan \delta<2.10^{-4}$ under applied field).

Agile materials with such low dielectric losses have already been reported, but for composite materials specially designed to reduce the dielectric loss by the combination of the ferroelectric phase with a dielectric one. For example, Liu et al. reported dielectric loss $\tan \delta \sim 3.10^{-4}$ on a $40 \mathrm{wt} . \% \mathrm{BSTZ}-60 \mathrm{wt} . \% \mathrm{MgO}$ ceramic [3], but with a lower tunability (6.2\%) and at a higher field ( $3 \mathrm{kV} / \mathrm{mm})$. Tunability $(25 \%)$ close to ours has been achieved in a BST $-1 \% \mathrm{Mn}-4 \% \mathrm{MgO}$ ceramic [28], but at a higher electric field $(1 \mathrm{kV} / \mathrm{mm})$ and with slightly higher losses $\left(\tan \delta=5.10^{-3}\right)$. Other comparisons can be made [29-31] which show that our tunability and dielectric loss values are located among the best reported up to now, so demonstrating that the novel STLT materials constitute effective ferroelectric compositions, moreover without the need of a doping or a combination with a dielectric compound.

Finally, the achievement of a ferroelectric transition near the room temperature for a layered-type perovskite oxide can be the starting point to explore alternative compositions and behaviors.

\section{Conclusion}

Original $\left(\mathrm{Sr}_{2} \mathrm{Ta}_{2} \mathrm{O}_{7}\right)_{100-\mathrm{x}}\left(\mathrm{La}_{2} \mathrm{Ti}_{2} \mathrm{O}_{7}\right)_{\mathrm{x}}$ materials were synthetized as powders and ceramics in order to explore their dielectric and ferroelectric properties in the radio frequency range. Composition (x) was varied between 0 and 5 and leads to an ideal solid solution with an evolution of the lattice parameters and cell volume following the Vegard's law. The dielectric characterization has shown that both relative permittivity $(\kappa)$ and dielectric loss ( $\tan \delta$ ) are stable in frequency from 1 to $100 \mathrm{kHz}$. At RT and fixed frequency, the relative permittivity increases then decreases with the composition (x); a maximum ( $\kappa=365)$ was reached for $\mathrm{x}=1.65(@ 10 \mathrm{kHz})$. Permittivity also peaks for a temperature $\left(\mathrm{T}_{\mathrm{M}}\right)$ shifting towards higher values with the amount of $\mathrm{La}_{2} \mathrm{Ti}_{2} \mathrm{O}_{7}$ ( $\mathrm{x}$ ) in the solid solution; compositions with $\mathrm{x} \geq 1.85$ have a $\mathrm{T}_{\mathrm{M}}$ higher than room temperature. Polarization-electric field (P-E) measurements have highlighted non-open loops for the compositions $\mathrm{x}=0$ and 1.65 , while hysteresis were obtained for $\mathrm{x}=1.85,2.0,2.5$ and 3.0, along with switching current peaks in I-E, thus confirming that these compositions are ferroelectrics at RT. The variation of the relative permittivity as a function of a DC electric field (i.e. tunability) was demonstrated for $x \geq 1.5$. A very high tunability $(18.1 \% @ 0.38 \mathrm{kV} / \mathrm{mm} ; 1 \mathrm{kHz})$ was obtained for the composition $\mathrm{x}=1.65$, associated with very low dielectric losses $\left(\tan \delta<2.10^{-3}\right)$. These new and high level performances $\operatorname{make}\left(\mathrm{Sr}_{2} \mathrm{Ta}_{2} \mathrm{O}_{7}\right)_{100-}$ ${ }_{x}\left(\mathrm{La}_{2} \mathrm{Ti}_{2} \mathrm{O}_{7}\right)_{x}$ promising lead-free ferroelectric materials which can compete with standard ferroelectrics. 


\section{ASSOCIATED CONTENT}

\section{Supporting Information}

Table S1. Values of lattice parameters and cell volume as a function of the composition $(\mathrm{x})$ of $\left(\mathrm{Sr}_{2} \mathrm{Ta}_{2} \mathrm{O}_{7}\right)_{100-\mathrm{x}}\left(\mathrm{La}_{2} \mathrm{Ti}_{2} \mathrm{O}_{7}\right)_{\mathrm{x}}$ powders.

Table S2. Values of the relative density as a function of the composition (x) of $\left(\mathrm{Sr}_{2} \mathrm{Ta}_{2} \mathrm{O}_{7}\right)_{100-\mathrm{x}}\left(\mathrm{La}_{2} \mathrm{Ti}_{2} \mathrm{O}_{7}\right)_{\mathrm{x}}$ ceramics.

Figure S3. Scanning electron microscopy surface morphologies of all the $\left(\mathrm{Sr}_{2} \mathrm{Ta}_{2} \mathrm{O}_{7}\right)_{100-\mathrm{x}}\left(\mathrm{La}_{2} \mathrm{Ti}_{2} \mathrm{O}_{7}\right)_{\mathrm{x}}$ ceramics sintered at $1500^{\circ} \mathrm{C}$ (compositions $\mathrm{x}$ are given below the micrographs).

Figure S4. Variation at 1,10 and $100 \mathrm{kHz}$ of the relative permittivity $(\kappa)$ as a function of a DC electric field for the $\mathrm{x}=1.65$ $\left(\mathrm{Sr}_{2} \mathrm{Ta}_{2} \mathrm{O}_{7}\right)_{100-\mathrm{x}}\left(\mathrm{La}_{2} \mathrm{Ti}_{2} \mathrm{O}_{7}\right)_{\mathrm{x}}$ ceramic (measurements made @ $\left.\mathrm{RT}\right)$.

Figure S5. Temperature $\theta-2 \theta$ X-rays diffractograms of the $\left(\mathrm{Sr}_{2} \mathrm{Ta}_{2} \mathrm{O}_{7}\right)_{100-\mathrm{x}}\left(\mathrm{La}_{2} \mathrm{Ti}_{2} \mathrm{O}_{7}\right)_{\mathrm{x}}$ powder with $\mathrm{x}=3($ data collected on a Panalytical Empirean diffractometer equipped with a Anton Paar HTK1200N temperature chamber).

\section{AUTHOR INFORMATION}

\section{Corresponding Author}

* claire.lepaven@univ-rennes1.fr

\section{Author Contributions}

The manuscript was written through contributions of all authors.

The authors declare no competing financial interest.

\section{ACKNOWLEDGMENT}

This work was supported by the European Union through the European Regional Development Fund (ERDF) and by the Ministry of Higher Education and Research, Brittany Région and Côtes d'Armor Département through the CPER Project MATECOM. This publication is also supported by Saint Brieuc Agglomération and the Syndicat de Gestion du Pole Universitaire de Saint Brieuc (France).

\section{REFERENCES}

[1] S. Gevorgian, A. Vorobiev, A. Deleniv, Ferroelectrics in microwave devices, circuits and systems physics, modeling, fabrication and measurements, in Engineering Materials and Processes, Springer, London, 2009, pp. 61e113.

[2] J. Lesseur, Imagerie 3D des matériaux et modélisations numériques : application aux multi-matériaux ferroélectriques, Thèse de doctorat en Sciences Chimiques de l'Université de Bordeaux (2015).

[3] C. Liu, P. Liu, G-G. Yao, X-B. Bian, H-X Jing, X-G. Lu, C-J. Gao, Improvement of dielectric thermal stability of BST ferroelectric material for tunable applications, Mater. Res. Bull. 46 (2011) 1510-1514.

[4] J. Lesseur, D. Bernard, U.-C. Chung, C. Estournès, M. Maglione, C. Elissalde, 3D mapping of anisotropic ferroelectric/dielectric composites, J. Eur. Ceram. Soc. 35 (2015) 337-345.

[5] V.A. Isupov, Crystal chemical aspects of the layered perovskite-like oxide ferroelectrics of the $A_{n} M_{n} 0_{3 n+2}$ type, Ferroelectrics 220 (1999) 79-103.

[6] A. Hushur, G. Shabbir, J-H. Ko, S. Kojima, The phase transitions of ferroelectric $\operatorname{Sr}_{2} \mathrm{Ta}_{2} \mathrm{O}_{7}$ crystals by MDSC, Brillouin and dielectric spectroscopy, J. Phys, D:Apply. Phys. 37 (2004) 1127-1131.

[7] H. Yan, H. Ning, Y. Kan, P. Wang, M. J. Reece, Piezoelectric ceramics with super-high Curie points, J. Am. Ceram. Soc. 92 (2009) 2270-2275.

[8] S. Nanamatsu, K. Kimura, K. Doi, S. Matsushita, N. Yamada, A new ferroelectric $\mathrm{La}_{2} \mathrm{Ti}_{2} \mathrm{O}_{7}$, Ferroelectrics 8 (1974) 511-513.

[9] H. Hao, M. Cao, Z. Guo, Z. Lu, S. Ouyang, Study on high temperature dielectric properties of La and Nb co-doped $\mathrm{Sr}_{2} \mathrm{Ta}_{2} \mathrm{O}_{7}$ ceramics, Functional Mater. 1 (2009) 104-106.

[10] S. Nanamatsu, M. Kimura, T. Kawamura, Crystallographic and dielectric properties of ferroelectric $\mathrm{A}_{2} \mathrm{~B}_{2} \mathrm{O}_{7}(\mathrm{~A}=\mathrm{Sr}, \mathrm{B}$ $=\mathrm{Ta}, \mathrm{Nb}$ ) crystals and their solid solutions, J. Phys. Soc. Jpn. 38 (1975) 817-824.

[11] K. Ohi, K. Ito, T. Sugata, M. Ohkoba, Phase Transitions in $\mathrm{Sr}_{2}\left(\mathrm{Nb}_{\mathrm{x}} \mathrm{Ta}_{1-\mathrm{x}}\right)_{2} \mathrm{O}_{7}$, J. Kor.Phys. Soc. 32 (1998) S59-S61. 
[12] Y. Fujimori, N. Izumi, T. Nakamura, Y. Shigematsu, Development of a low dielectric constant material for the ferroelectric memory field effect transistor, Jpn. J; Appl. Phys. 36 (1997) 5935-5938.

[13] K. Kato, Surface morphology and dielectric properties of alkoxy-derived $\mathrm{Sr}_{2} \mathrm{Ta}_{2} \mathrm{O}_{7}$ and $\mathrm{Sr}_{2}(\mathrm{Ta}, \mathrm{Nb})_{2} \mathrm{O}_{7}$ thin films, J. Mater. Sci.: Mater. Elec. 11 (2000) 575-578.

[14] I. Takahashi, K. Azumi, Y. Shirai, M. Hirayama, A. Teramoto, S. Sugawa, T. Ohmi, Fabrication of $\mathrm{Pt} / \mathrm{Sr}_{2}\left(\mathrm{Ta}_{1-}\right.$ $\left.{ }_{x}, \mathrm{Nb}_{\mathrm{x}}\right)_{2} \mathrm{O}_{7} / \mathrm{SiO}_{2} / \mathrm{Si}$ field-effect transistor for one-transistor-type ferroelectric random access memory, Proceedings of the 6th WSEAS International Conference on Microelectronics, Nanoelectronics, Optoelectronics, 2007, Istanbul, Turkey, May $27-$ 29.

[15] D. Fasquelle, J.C. Carru, L. Le Gendre, C. Le Paven, J. Pinel, F. Cheviré, F. Tessier, R. Marchand, Lanthanum titanate ceramics: Electrical characterizations in large temperature and frequency ranges, J. Eur. Ceram. Soc. 25 (2005) 2085-2088.

[16] C. Le Paven, Y. Lu, H.V. Nguyen, R. Benzerga, L. Le Gendre, S. Rioual, D. Benzegoutta, F. Tessier, F. Cheviré, A. Sharaiha, C. Delaveaud, X. Castel, Lanthanum titanium perovskite compound: thin film deposition and high frequency dielectric characterization, Thin Solid Films 553 (2014) 76-80.

[17] C. Le Paven, R. Benzerga, A. Ferri, D. Fasquelle, V. Laur, L. Le Gendre, F. Marlec, F. Tessier, F. Cheviré, R. Desfeux, S. Saitzek, X. Castel, A. Sharaiha, Ferroelectric and dielectric study of strontium tantalum based perovskite oxynitride films deposited by reactive rf magnetron sputtering, Mater. Res. Bull. 96P2 (2017) 126-132.

[18] J. Rodríguez-Carvajal, Recent Advances in Magnetic Structure Determination by Neutron Powder Diffraction, Phys. B Condens. Mater. 192 (1993) 55-69.

[19] R.D. Shannon, C.T. Prewitt, Effective ionic radii in oxides and fluorides, Acta Cryst. B 25 (1969) 925-946.

[20] H. Kato, A. Kudo, Energy structure and photocatalytic activity for water splitting of $\mathrm{Sr}_{2}\left(\mathrm{Ta}_{1-\mathrm{x}} \mathrm{Nb}_{\mathrm{x}}\right)_{2} \mathrm{O}_{7}$ solid solution, J. Photochem. Photobiol. A: Chem. 145 (2001) 129-133.

[21] J. Petzelt, S. Kamba, J. Hlinka, Ferroelectric soft modes in ceramics and films, in New Developments in Advanced Functional Ceramics (Eds L. Mitoseriu), Indian Series of Applied Physic, Transworld Research Network 37/661, Trivandrum, Kerala, India 2007, pp. 387-421.

[22] Y-J. Song, Ferroelectric thin films for high density non-volatile memories, Doctoral Dissertation Virginia Polytechnic Institute and State University (1998).

[23] D. Fasquelle, J.C. Carru, L. Le Gendre, C. Le Paven, J. Pinel, F. Cheviré, F. Tessier, R. Marchand, Lanthanum titanate ceramics: Electrical characterizations in large temperature and frequency ranges, J. Eur. Ceram. Soc. 25 (2005) 2085-2088.

[24] N. Ishizawa, F. Maruno, S. Iwai, Compounds with perovskite-type slabs. IV Ferroelectric phase transitions in $\operatorname{Sr}_{2}\left(\mathrm{Ta}_{1-}\right.$ $\left.{ }_{\mathrm{x}} \mathrm{Nb}_{\mathrm{x}}\right)_{2} \mathrm{O}_{7}(\mathrm{x} \sim 0.12)$ and $\mathrm{Sr}_{2} \mathrm{Ta}_{2} \mathrm{O}_{7}$, Acta Cryst. B 37 (1981) 26-31.

[25] C. Liu, P. Liu, Microstructure and dielectric properties of BST ceramics derived from high-energy ball-milling, J. Alloys Comp. 584 (2014) 114-118.

[26] K. M. Ok, P. S. Halasyamani, D. Casanova, M. Llunell, P. Alemany, S. Alvarez, Distortions in octahedrally coordinated d $\mathrm{d}^{0}$ transition metal oxides: a continuous Symmetry measures approach, Chem. Mater. 18 (2006) 3176-3183.

[27] J. Lopez-Perez, J. Iniguez, Ab initio study of proper topological ferroelectricity in layered perovskite $\mathrm{La}_{2} \mathrm{Ti}_{2} \mathrm{O}_{7}, \mathrm{Phys}$ Rev. B 84 (2011) 075121.

[28] C. Elissalde, U.-C. Chung, G. Philippot, J. Lesseur, R. Berthelot, D. Sallagoity, M. Albino, R. Epherre, G. Chevallier, S. Buffière, A. Weibel, D. Bernard, J. Majimel, C. Aymonier, S. Mornet, C. Estournès, M. Maglione, Innovative architectures in ferroelectric multi-materials: chemistry, interfaces and strain, J. Advanc. Dielec. 5 (2015) 1-11.

[29] R.E. Stanculescu, C. E. Ciomaga, N. Horchidan, C. Galassi, F. M. Tufescu, L. Mitoseriu, The influence of postsintering re-oxidation treatment on dielectric response of dense and porous $\mathrm{Ba}_{0.70} \mathrm{Sr}_{0.30} \mathrm{TiO}_{3}$ ceramics, Ceram. Int. 42 (2016) 527-536.

[30] R. Liang, Z. Zhou, X. Dong, G. Wang, F. Cao, Z. Hu, K. Jiang, Enhanced dielectric tunability of $\mathrm{Ba}_{0.55} \mathrm{Sr}_{0.45} \mathrm{TiO}_{3^{-}}$ $\mathrm{ZnAl}_{2} \mathrm{O}_{4}$ composite ceramic, Ceram. Int. 41 (2015) S551-S556.

[31] Q. Zhang, F. Gao, G. Hu, C. Zhang, M. Wang, M. Qin, Characterization and dielectric properties of modified $\mathrm{Ba}_{0.6} \mathrm{Sr}_{0.4} \mathrm{TiO}_{3} /$ poly(vinylidene fluoride) composites with high dielectric tunability, Compos. Sci. Technol. 118 (2015) 94100 . 


\section{Graphical Abstract}
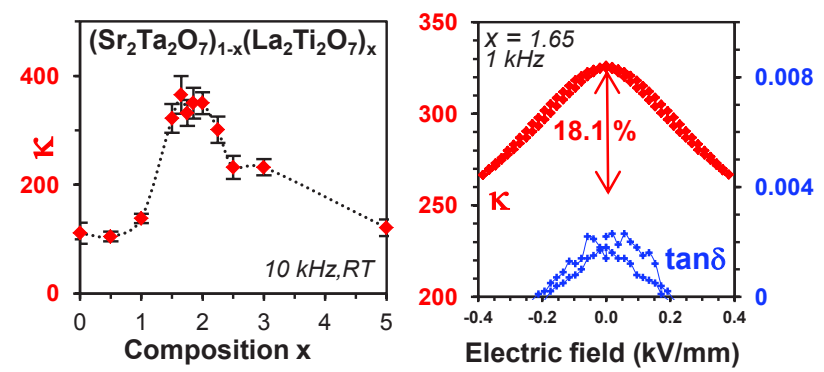